\title{
Application of Five-Level NPC inverter in DPC- ANN of Doubly Fed Induction Generator for Wind Power Generation Systems
}

\author{
Habib Benbouhenni \\ * Laboratoire d'Automatique et d'Analyse des Systèmes (LAAS), Departement de Génie Electrique, Ecole Nationale \\ Polytechnique d'Oran Maurice Audin, Oran, Algeria. \\ (habib0264@gmail.com ) \\ *Corresponding Author; Habib Benbouhenni, BP: 50B Ouled Fares Chlef Algeria, Tel: +213663956329, \\ habib0264@gmail.com
}

Received: 04.07.2019 Accepted:07.09.2019

\begin{abstract}
This paper presents the five-level direct power control (DPC) using artificial neural networks (ANNs) controller of a doubly fed induction generator (DFIG) based wind power generation systems (WPGSs). The validity of the proposed strategies is verified by simulation tests of an induction generator. The harmonic distortion of stator current, reactive power, and stator active power are determined and compared to the above strategies. The five-level DPC strategy with ANN controller is shown to be able to minimize the reactive power, harmonic distortion of stator current, and stator active power ripples and to improve performance DPC control scheme.
\end{abstract}

Keywords: Five-level DPC, DFIG, WPGSs, ANNs.

\section{Introduction}

The direct torque control (DTC) was first applied for the induction motor by Takahashi and Depenbrock in 1980's [1]. This control scheme is simple and easy to implement. In this strategy, two hysteresis comparators, namely flux and electromagnetic torque controllers are selected to determine the inverter instantaneous switching state [2]. In [3], a DTC strategy was proposed to control PMSM. A DTC technique was designed to control the DFIG [4]. In [5], a modified DTC control was proposed based on second order sliding mode controller (SOSMC) to control DFIG-based wind power conversion system (WPCS). Similar to the DTC strategy, a direct power control (DPC) of a DFIG based wind turbine systems has been proposed recently [6-8].

The DPC strategy is simple and alternative approach control formulation that does not require decomposition into symmetrical components, the DPC strategy has been proved to be preponderant for DFIGs due to the simple implementation [9]. The basic idea of the DPC technique is a direct control of the stator reactive and active powers without any internal control loop or PWM strategy. However, the DPC techniques obtain fast response time and less dependence on DFIG parameters [10]. In [11], the authors propose a three-level DPC control to regulate stator reactive and active powers of the DFIG-based WPCSs. In [12, 13], DPC strategy was proposed based on space vector modulation (SVM) to control DFIG based wind turbine. Sliding mode direct power control [14]. In [15], a modified DPC strategy was proposed based on SOSMC controller to reduced harmonic distortion of current and powers ripples. Model predictive direct power control [16]. In this paper, a neural DPC strategy is proposed to control the DFIG using a five-level neutral point clamped (NPC) inverter. This proposed control scheme allows reducing the harmonics in the current, reactive and active powers ripples compared to conventional five-level DPC strategy and classical DPC control scheme. Section II is dedicated to the modeling of the DFIG machine. In section III of this paper, the basic principles of the proposed DPC strategy has been shortly introduced. Section IV presents the proposed DPC strategy with neural networks controller. Section V presents the simulation results of the both techniques. Finally, conclusion has given in section VI.

\section{Modeling of the DFIG}

The doubly fed induction generator dynamic behavior in a synchronous reference frame can be represented by the 
Park's equations, provided all the rotor quantities are referred to the stator side $[17,18]$.

Rotor flux components :

$\left\{\begin{array}{l}\psi_{d r}=L_{r} I_{d r}+M I_{d r} \\ \psi_{q r}=L_{r} I_{q r}+M I_{q r}\end{array}\right.$

Where : $\Psi_{\mathrm{dr}}$ and $\Psi_{\mathrm{qr}}$ are the rotor fluxes

$\mathrm{L}_{\mathrm{r}}$ is the inductance of the rotor

$\mathrm{M}$ is the mutual inductance

$\mathrm{I}_{\mathrm{dr}}$ and $\mathrm{I}_{\mathrm{qr}}$ are the rotor currents.

Stator flux components :

$\left\{\begin{array}{l}\psi_{d s}=L_{s} I_{d s}+M I_{d r} \\ \psi_{q s}=L_{s} I_{q s}+M I_{q r}\end{array}\right.$

Where : $\Psi_{\mathrm{qs}}$ and $\Psi_{\mathrm{ds}}$ are the stator fluxes.

$\mathrm{L}_{\mathrm{s}}$ is the inductance of the stator.

Stator voltage components :

$$
\left\{\begin{array}{l}
V_{d s}=R_{s} I_{d s}+\frac{d}{d t} \psi_{d s}-\omega_{s} \psi_{q s} \\
V_{q s}=R_{s} I_{q s}+\frac{d}{d t} \psi_{q s}+\omega_{s} \psi_{d s}
\end{array}\right.
$$

Where : $\mathrm{V}_{\mathrm{ds}}$ and $\mathrm{V}_{\mathrm{qs}}$ are the stator Voltages

$\mathrm{R}_{\mathrm{S}}$ is the stator resistance

$\omega_{s}$ : is the electrical pulsation of the stator.

Rotor voltage components :

$$
\left\{\begin{array}{l}
V_{d r}=R_{r} I_{d r}+\frac{d}{d t} \psi_{d r}-\omega_{r} \psi_{q r} \\
V_{q r}=R_{r} I_{q r}+\frac{d}{d t} \psi_{q r}+\omega_{r} \psi_{d r}
\end{array}\right.
$$

Where : $\mathrm{V}_{\mathrm{dr}}$ and $\mathrm{V}_{\mathrm{qr}}$ are the rotor voltages.

$\mathrm{R}_{\mathrm{r}}$ is the rotor resistance.
The stator side active and reactive powers are defined as:

$$
\left\{\begin{array}{l}
P_{s}=\frac{3}{2}\left(V_{d s} I_{d s}+V_{q s} I_{q s}\right) \\
Q_{s}=\frac{3}{2}\left(V_{q s} I_{d s}-V_{d s} I_{q s}\right)
\end{array}\right.
$$

Where: $P_{s}$ is the stator active power

$\mathrm{Q}_{\mathrm{s}}$ is the stator reactive power.

The torque can be written as follows:

$$
T_{e}=\frac{3}{2} p \frac{M}{L_{r}}\left(I_{d r} \cdot \psi_{q s}-I_{q r} \cdot \psi_{d s}\right)
$$

Where $: p$ is the number of pole pairs.

$\mathrm{T}_{\mathrm{e}}$ is the electromagnetic torque

The electrical model of the DFIG is completed by the following mechanical equation:

$$
T_{e}-T_{r}=J \cdot \frac{d \Omega}{d t}+f \cdot \Omega
$$

Where : $\Omega$ is the mechanical rotor speed.

$J$ is the inertia

$f$ is the viscous friction coefficient

$T_{r}$ is the load torque.

\section{Five-level DPC control}

The DPC goal is to control the stator active and reactive powers of the DFIG-based wind energy conversion systems. This strategy is based on the same control principles as in the DTC control scheme. In DTC, it's the rotor flux and the electromagnetic torque which are directly controlled, while in DPC strategy, it's the reactive and active stator powers, which are directly controlled [19]. The traditional DPC, which is designed to control stator reactive and active powers of the DFIG, is shown in Fig. 1.

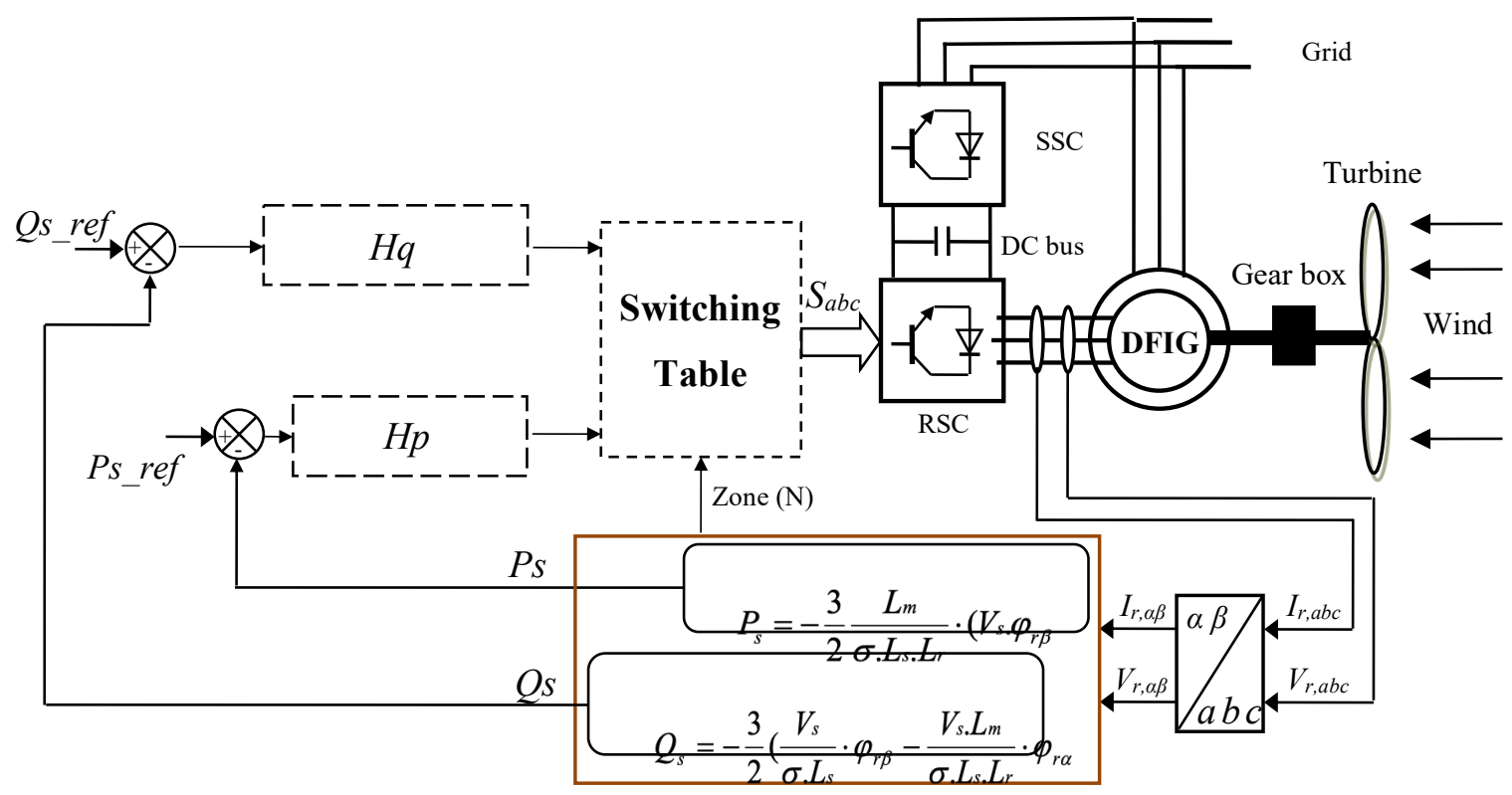

Reactive and active power estimation

Fig. 1 Traditional DPC control. 
The Cascaded H-bridge, Flying capacitor, Diode clamped inverter (DCI) are the three main different multilevel inverter structures which are used in industrial applications with separate dc sources [20]. However, the DCI is one of the most interesting solutions, to increase power levels and voltage.
The five-level DCI inverter is proposed in this paper which overcome the drawbacks of the traditional inverter. The representation of the space voltage vectors of the fivelevel NPC inverter for all switching states is given by Fig. 2 [21].

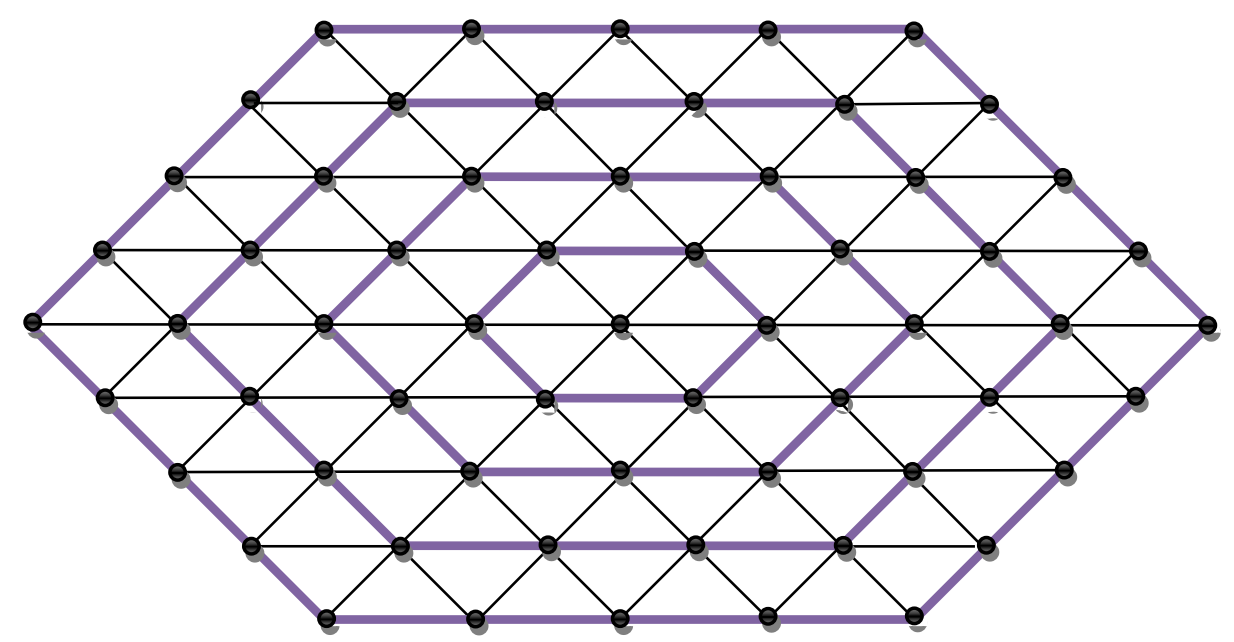

Fig. 2 Five-level inverter vectors representations.

Active and stator reactive powers is estimated using (1) and (2) [22].

$$
\begin{aligned}
P_{s} & =-\frac{3}{2} \frac{L_{m}}{\sigma \cdot L_{s} \cdot L_{r}} \cdot\left(V_{s} \cdot \psi_{r \beta}\right) \\
Q_{s} & =-\frac{3}{2}\left(\frac{V_{s}}{\sigma \cdot L_{s}} \cdot \psi_{r \beta}-\frac{V_{s} \cdot L_{m}}{\sigma \cdot L_{s} \cdot L_{r}} \cdot \psi_{r \alpha}\right)
\end{aligned}
$$

Where: $\mathrm{Lm}$ is the mutual inductance $\Psi_{\mathrm{r} \beta}$ : is the rotor flux linkage of $\beta$-axis. $\Psi_{\mathrm{r} \alpha}:$ is the rotor flux linkage of $\alpha$-axis.

$$
\Psi_{s \alpha}=\sigma L_{r} I_{r \alpha}+\frac{M}{L_{s}} \Psi_{s}
$$

Where : $\Psi_{\mathrm{s} \alpha}$ : is the stator flux linkage of $\alpha$-axis.

$\Psi_{\text {s }}$ is the stator flux.

$\mathrm{I}_{\mathrm{r} \alpha}:$ is the rotor current linkage of $\alpha$-axis.

$$
\Psi_{s \beta}=\sigma L_{r} I_{r \beta}
$$

Where : $\Psi_{\mathrm{s} \beta}$ : is the stator flux linkage of $\beta$-axis. $\mathrm{I}_{\mathrm{r} \beta}:$ is the rotor current linkage of $\beta$-axis.

$$
\left|\overline{\Psi_{s}}\right|=\frac{\left|\overline{V_{s}}\right|}{w_{s}}
$$

Where : $\mathrm{V}_{\mathrm{s}}$ is the stator voltage.

$$
\sigma=1-\frac{M^{2}}{L_{r} L_{s}}
$$

The reactive and active powers can be reformulated by inducing angle $\lambda$ between the rotor and stator vectors as follows :

$$
\begin{aligned}
& P_{s}=-\frac{3}{2} \frac{L_{m}}{\sigma \cdot L_{s} \cdot L_{r}} w_{s}\left|\psi_{s}\right|\left|\psi_{r}\right| \sin (\lambda) \\
& Q_{s}=-\frac{3}{2} \frac{w_{s}}{\sigma \cdot L_{s}}\left|\psi_{s}\right|\left(\frac{M}{L_{r}}\left|\psi_{r}\right| \cos (\lambda)-\mid \psi_{s}\right)
\end{aligned}
$$

The derivation of the active and reactive powers can given by:

$$
\begin{aligned}
\frac{d P_{s}}{d t} & =-\frac{3}{2} \frac{L_{m}}{\sigma \cdot L_{s} \cdot L_{r}} w_{s}\left|\psi_{s}\right| \frac{d\left(\left|\psi_{r}\right| \sin (\lambda)\right)}{d t} \\
\frac{d Q_{s}}{d t} & =-\frac{3}{2} \frac{M \cdot w_{s}}{\sigma \cdot L_{r} L_{s}}\left|\psi_{s}\right|\left(\frac{d\left(\left|\psi_{r}\right| \cos (\lambda)\right)}{d t}\right)
\end{aligned}
$$

On the other hand, the magnitude of stator flux, which can be estimated by:

$$
\left\{\begin{aligned}
\Psi_{s \alpha}= & \int_{0}^{t}\left(V_{s \alpha}-R_{s} I_{s \alpha}\right) d t \\
& 0 \\
\Psi_{s \beta}= & \int_{0}^{t}\left(V_{s \beta}-R_{s} I_{s \beta}\right) d t
\end{aligned}\right.
$$

Where $: V_{s \alpha}$ is the stator voltage linkage of $\alpha$-axis. $\mathrm{V}_{\mathrm{s} \beta}$ : is the stator voltage linkage of $\beta$-axis.

The stator flux amplitude is given by:

$$
\Phi_{s}=\sqrt{\Psi_{S \alpha}^{2}+\Psi_{s \beta}^{2}}
$$


INTERNATIONAL JOURNAL Of SMART GRID

Habib Benbouhenni, Vol.3, No.3, September, 2019

The stator flux angle is calculated by :

$$
\theta_{S}=\operatorname{arctg}\left(\frac{\Psi_{s \beta}}{\Psi_{s \alpha}}\right)
$$

In five-level DPC strategy a two-level hysteresis comparator (Fig. 3) is used for the reactive power (Hq) and a seven-level hysteresis comparator (Fig. 4) for the stator active power (Hp). Finally, based on the values of constants $\mathrm{Hp}$ and $\mathrm{Hq}$ and the position of the stator flux (24 region control), the inverter switching algorithm is as shown in Table 1.
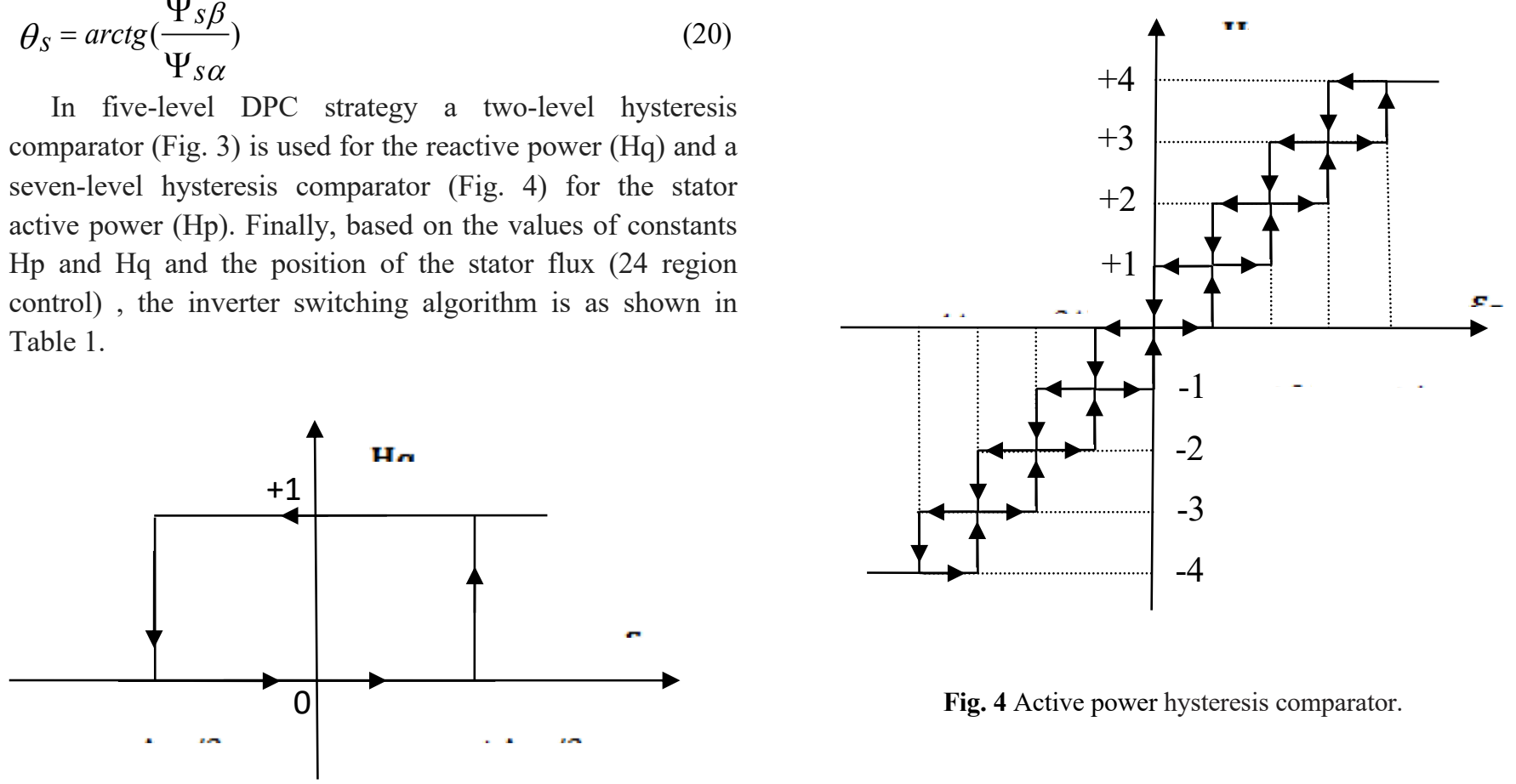

Fig. 4 Active power hysteresis comparator.

Fig. 3 Reactive power hysteresis comparator.

Table 1. Switching table of five-level DPC control

\begin{tabular}{|c|c|c|c|c|c|c|c|c|c|c|c|c|c|c|c|c|c|c|}
\hline \multirow{4}{*}{$\mathbf{N}$} & \multicolumn{18}{|c|}{ Cflx } \\
\hline & \multicolumn{9}{|c|}{1} & \multicolumn{9}{|c|}{0} \\
\hline & \multicolumn{18}{|c|}{ Cepl } \\
\hline & 4 & 3 & 2 & 1 & $\mathbf{0}$ & -1 & -2 & -3 & -4 & 4 & 3 & 2 & 1 & 0 & -1 & -2 & -3 & -4 \\
\hline 1 & 24 & 23 & 22 & 21 & 0 & 41 & 42 & 46 & 48 & 18 & 16 & 12 & 11 & 0 & 51 & 52 & 53 & 54 \\
\hline 2 & 25 & 23 & 22 & 21 & 0 & 41 & 42 & 49 & 50 & 20 & 19 & 12 & 11 & 0 & 51 & 52 & 53 & 55 \\
\hline 3 & 28 & 26 & 27 & 21 & 0 & 41 & 47 & 53 & 54 & 24 & 23 & 17 & 11 & 0 & 51 & 57 & 56 & 58 \\
\hline 4 & 30 & 29 & 27 & 21 & 0 & 41 & 47 & 53 & 55 & 25 & 23 & 17 & 11 & 0 & 51 & 57 & 59 & 60 \\
\hline 5 & 34 & 33 & 32 & 31 & 0 & 51 & 52 & 56 & 58 & 28 & 26 & 22 & 21 & 0 & 1 & 2 & 3 & 4 \\
\hline 6 & 35 & 33 & 32 & 31 & 0 & 51 & 52 & 59 & 60 & 30 & 29 & 22 & 21 & 0 & 1 & 2 & 3 & 5 \\
\hline 7 & 38 & 36 & 37 & 31 & 0 & 51 & 57 & 3 & 4 & 34 & 33 & 27 & 21 & 0 & 1 & 7 & 6 & 8 \\
\hline 8 & 40 & 39 & 37 & 31 & 0 & 51 & 57 & 3 & 5 & 35 & 33 & 27 & 21 & 0 & 1 & 7 & 9 & 10 \\
\hline 9 & 44 & 43 & 42 & 41 & 0 & 1 & 2 & 6 & 8 & 38 & 36 & 32 & 31 & 0 & 11 & 12 & 13 & 14 \\
\hline 10 & 45 & 43 & 42 & 41 & 0 & 1 & 2 & 9 & 10 & 40 & 39 & 32 & 31 & 0 & 11 & 12 & 13 & 15 \\
\hline 11 & 48 & 46 & 47 & 41 & 0 & 1 & 7 & 13 & 14 & 44 & 43 & 37 & 31 & 0 & 11 & 17 & 16 & 18 \\
\hline 12 & 50 & 49 & 47 & 41 & 0 & 1 & 7 & 13 & 15 & 45 & 43 & 37 & 31 & 0 & 11 & 17 & 19 & 20 \\
\hline 13 & 54 & 53 & 52 & 51 & 0 & 11 & 12 & 16 & 18 & 48 & 46 & 42 & 41 & 0 & 21 & 22 & 23 & 54 \\
\hline 14 & 55 & 53 & 52 & 51 & 0 & 11 & 12 & 19 & 20 & 50 & 49 & 42 & 41 & 0 & 21 & 22 & 23 & 24 \\
\hline 15 & 58 & 56 & 57 & 51 & 0 & 11 & 17 & 23 & 24 & 54 & 53 & 47 & 41 & 0 & 21 & 27 & 26 & 25 \\
\hline 16 & 60 & 59 & 57 & 51 & 0 & 11 & 17 & 23 & 25 & 55 & 53 & 47 & 41 & 0 & 21 & 27 & 29 & 28 \\
\hline 17 & 4 & 3 & 2 & 1 & 0 & 21 & 22 & 26 & 28 & 58 & 56 & 52 & 51 & 0 & 31 & 32 & 33 & 30 \\
\hline 18 & 5 & 3 & 2 & 1 & 0 & 21 & 22 & 29 & 30 & 60 & 59 & 52 & 51 & 0 & 31 & 32 & 33 & 34 \\
\hline 19 & 8 & 6 & 7 & 1 & 0 & 21 & 27 & 33 & 34 & 4 & 3 & 57 & 51 & 0 & 31 & 37 & 36 & 35 \\
\hline 20 & 10 & 9 & 7 & 1 & 0 & 21 & 27 & 33 & 35 & 5 & 3 & 57 & 51 & 0 & 31 & 37 & 39 & 38 \\
\hline 21 & 14 & 13 & 12 & 11 & 0 & 31 & 32 & 36 & 38 & 8 & 6 & 2 & 1 & 0 & 41 & 42 & 43 & 40 \\
\hline 22 & 15 & 13 & 12 & 11 & 0 & 31 & 32 & 39 & 40 & 10 & 9 & 2 & 1 & 0 & 41 & 42 & 43 & 44 \\
\hline 23 & 18 & 16 & 17 & 11 & 0 & 31 & 37 & 43 & 44 & 14 & 13 & 7 & 1 & 0 & 41 & 47 & 46 & 45 \\
\hline 24 & 20 & 19 & 17 & 11 & 0 & 31 & 37 & 43 & 45 & 15 & 13 & 7 & 1 & 0 & 41 & 47 & 49 & 48 \\
\hline
\end{tabular}




\section{Five-level DPC-ANN control}

In order to improve the five-level DPC performances a complimentary use of neural controller is proposed. The principle of five-level neural DPC control (DPC-ANN) is similar to five-level DPC strategy. The difference is using an neural controller to replace the switching table with stator active power hysteresis comparator, reactive power hysteresis comparator and sector as inputs. The switching $\left(\mathrm{S}_{\mathrm{a}}, \mathrm{S}_{\mathrm{b}}\right.$ and $\left.\mathrm{S}_{\mathrm{c}}\right)$ of the inverter will be the control output. As shown in Fig. 5.

This proposed strategy reduced harmonic distortion of stator current, stator reactive and active ripples compared to five-level DPC control scheme. This control scheme is simple and easy to implement. On the other hand, the proposed neural controller is the retropropagation of Levenberg-Marquardt (LM). The parameters of the LM algorithm is shown in Table 2. The structure of neural switching table is illustrated in the Fig. 6.
Table 2. Parameters of the LM algorithm

\begin{tabular}{|l|c|}
\hline Parameters of the LM & Values \\
\hline Number of hidden layer & 12 \\
\hline TrainParam.Lr & 0.02 \\
\hline TrainParam.show & 50 \\
\hline TrainParam.eposh & 1000 \\
\hline $\begin{array}{l}\text { Coeff of acceleration of } \\
\text { convergence (mc) }\end{array}$ & 0.9 \\
\hline TrainParam.goal & 0 \\
\hline TrainParam.mu & 0.9 \\
\hline Functions of activation & Tensing, Purling, gensim \\
\hline
\end{tabular}

The block diagram of the neural controller of the switching table is given by Fig. 7. The structure of layer 1 and layer 2 is shown in Fig. 8 and Fig. 9 respectively.

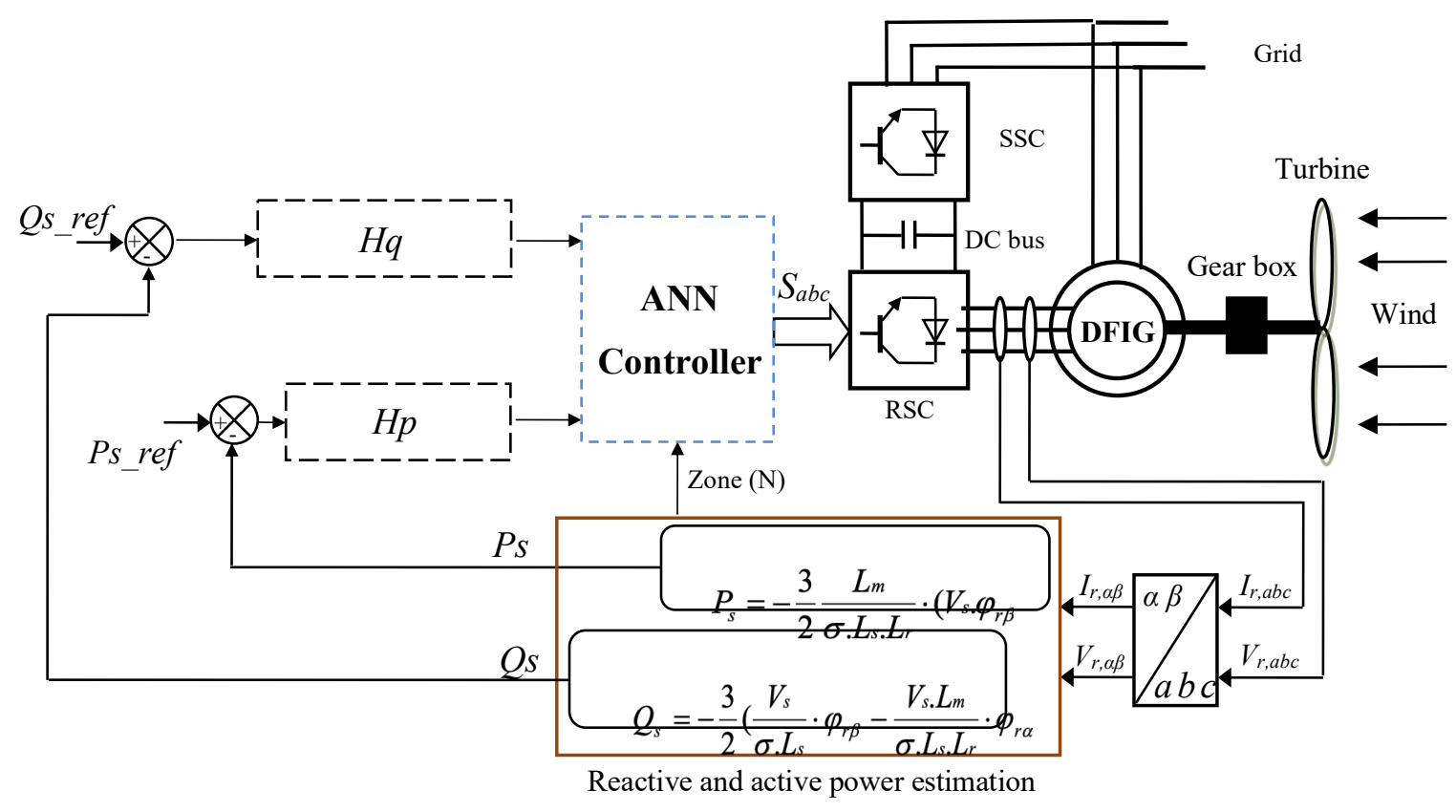

Fig. 5 DPC-ANN control.

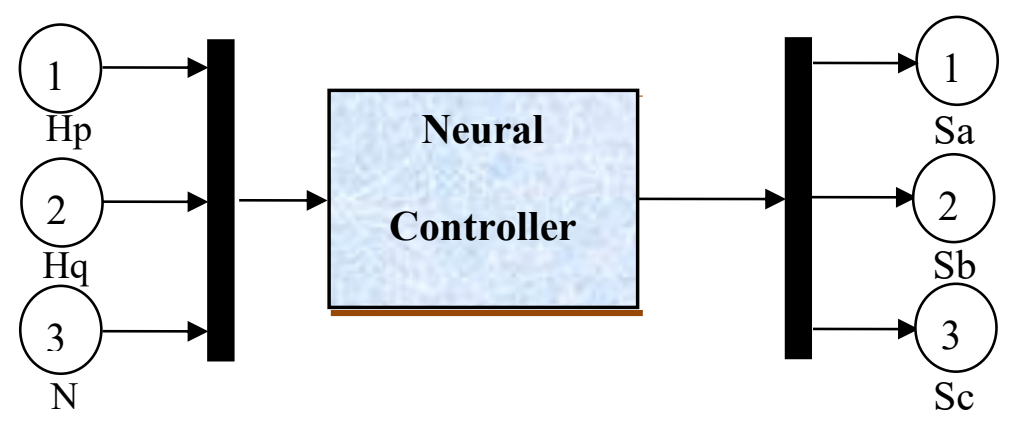

Fig. 6 Block diagram of the neural switching table. 


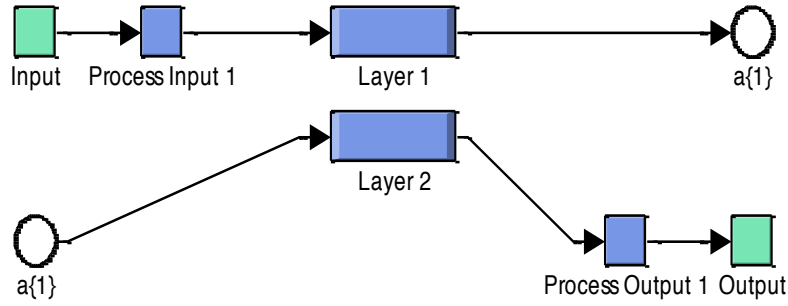

Fig. 7 Block diagram of the switching table.

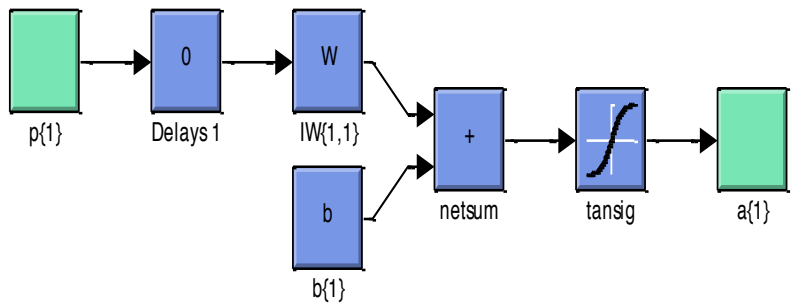

Fig. 8 Layer 1.

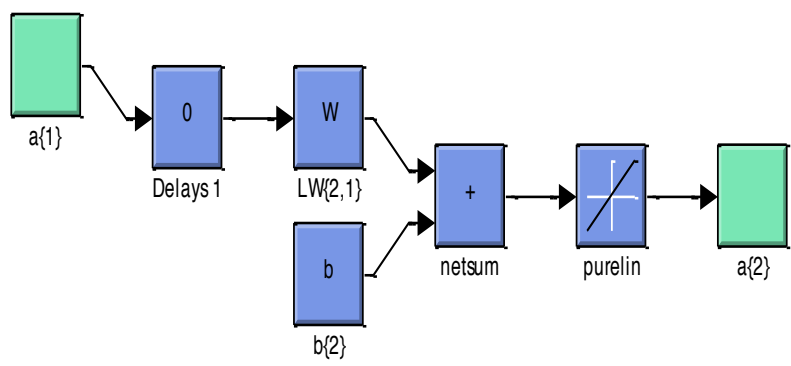

Fig. 9 Layer 2.

\section{Simulation results}

The simulation results of five-level DPC-ANN control scheme of DFIG are compared with conventional five-level DPC strategy. The performance analysis is done with stator reactive power, harmonic distortion of stator current and stator active power. The DFIG used in this case study is a $1.5 \mathrm{MW}, 380 / 696 \mathrm{~V}$, two poles, $50 \mathrm{~Hz}$; with the following parameters: $\mathrm{Rs}=0.012 \Omega, \mathrm{Rr}=0.021 \Omega, \mathrm{Ls}=0.0137 \mathrm{H}, \mathrm{Lr}=$ $0.0136 \mathrm{H}$ and $\mathrm{Lm}=0.0135 \mathrm{H}$. The system has the following mechanical parameters: $\mathrm{J}=1000 \mathrm{~kg} . \mathrm{m} 2, \mathrm{fr}=0.0024 \mathrm{Nm} / \mathrm{s}$. A. Reference tracking test (RTT)

Figs. 10-11 shows the THD of stator current of the PMSM obtained using FFT (Fast Fourier Transform) method for five-level DPC strategy and five-level DPC-ANN control scheme one respectively. It can be clearly observed that the THD is minimized for five-level DPC-ANN when compared to five-level DPC strategy. Table 3 shows the comparative analysis of THD value.

For the five-level DPC strategy and five-level DPC$\mathrm{ANN}$, the stator reactive power and stator active power, tracks almost perfectly their references values (see Figs. 1213).

Stator active power response comparing curves are shown in Fig. 14. See figure the active power ripple is significantly reduced when the five-level DPC-ANN control scheme is in use.

Fig. 15 shows the stator reactive power responses of both the five-level DPC and five-level DPC-ANN control scheme. It is found that the proposed DPC exhibits smooth response and lesser ripple in stator reactive power as compared to the fivelevel DPC control scheme.

Table 3. Comparative analysis of THD value (RTT)

\begin{tabular}{|l|c|c|}
\cline { 2 - 3 } \multicolumn{1}{c|}{} & \multicolumn{2}{c|}{ THD (\%) } \\
\cline { 2 - 3 } \multicolumn{1}{c|}{ Five-level DTC } & Five-level DTC-ANN \\
\hline
\end{tabular}

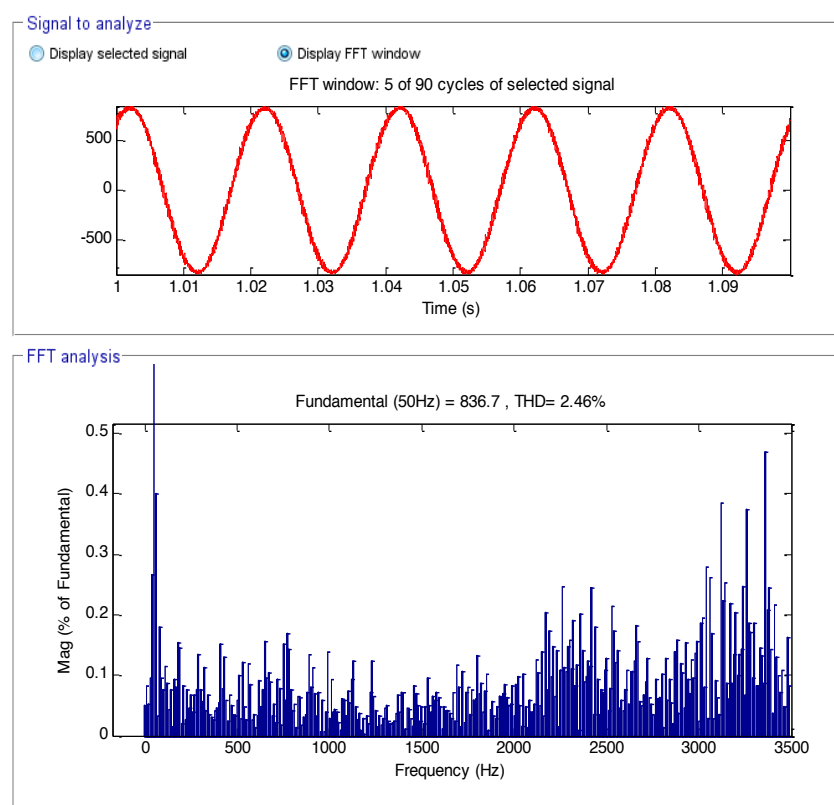

Fig. 10 Spectrum harmonic of stator current (Five-level DPC).
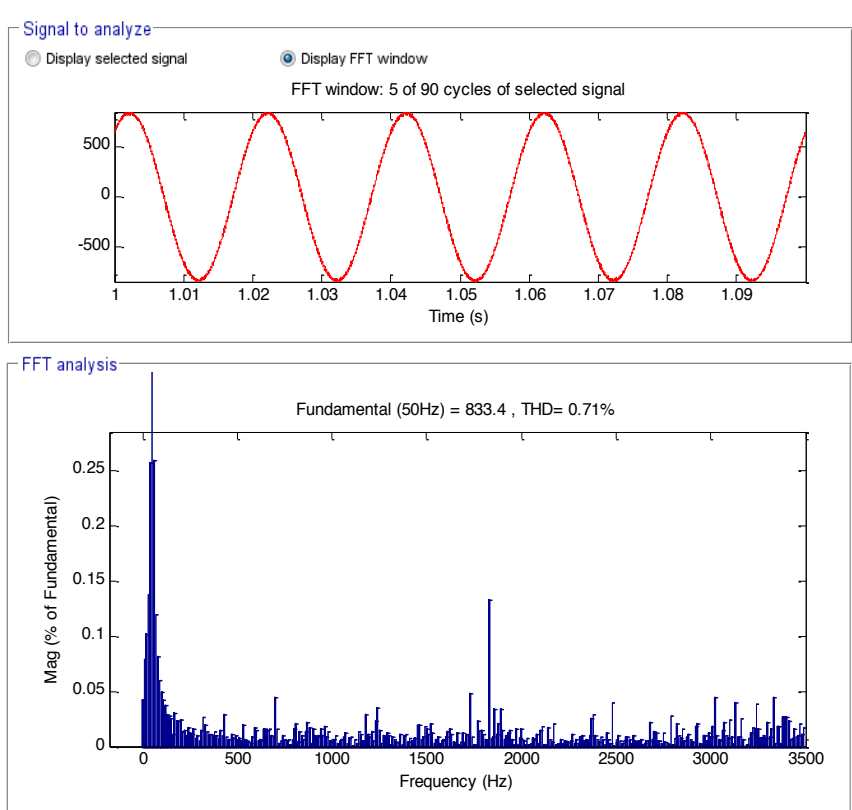

Fig. 11 Spectrum harmonic of stator current (Five-level DPC-ANN) 


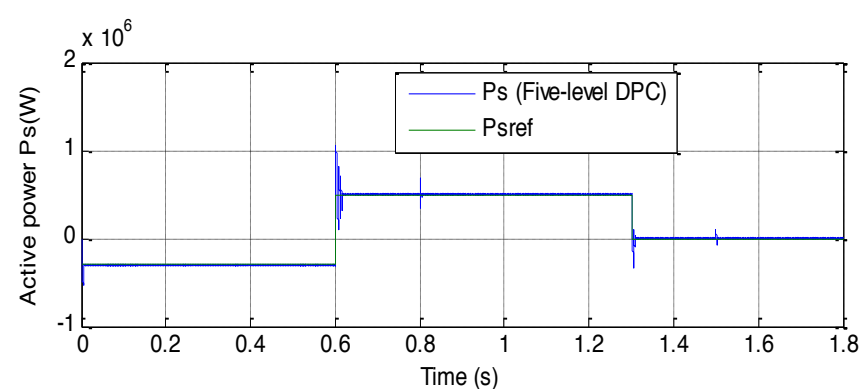

a)DPC

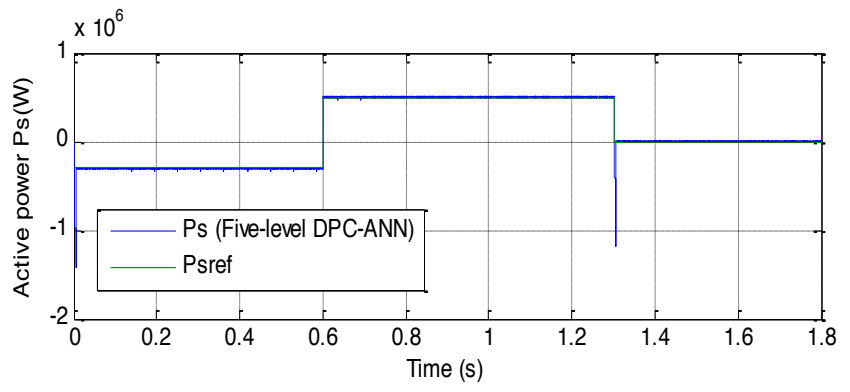

b)Five-level DPC-ANN

Fig. 12 Active power (RTT).

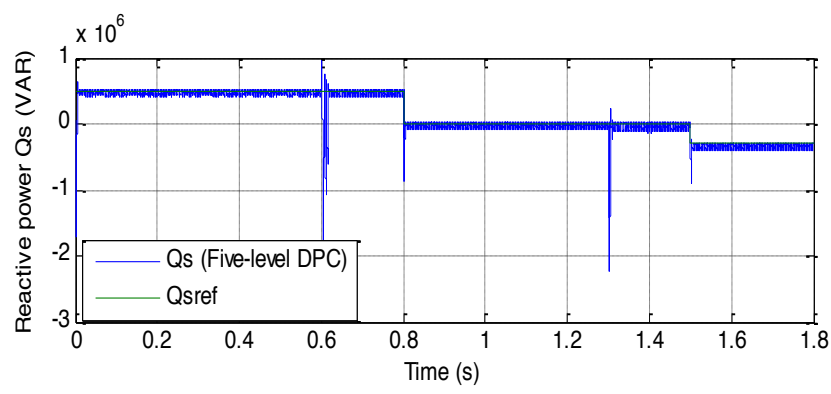

a)DPC

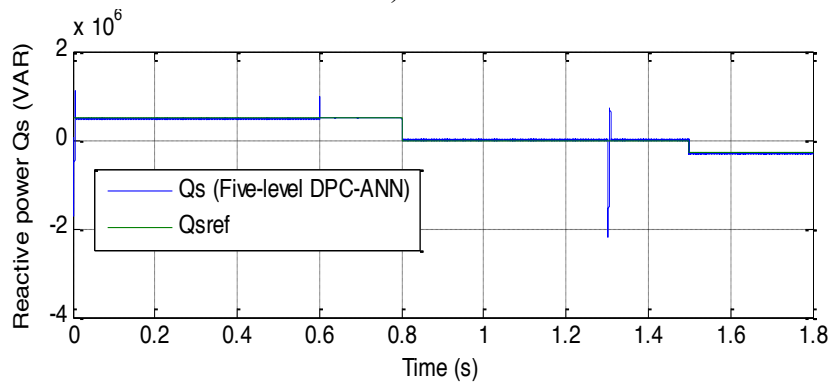

b) Five-level DPC-ANN

Fig. 13 Reactive power (RTT).

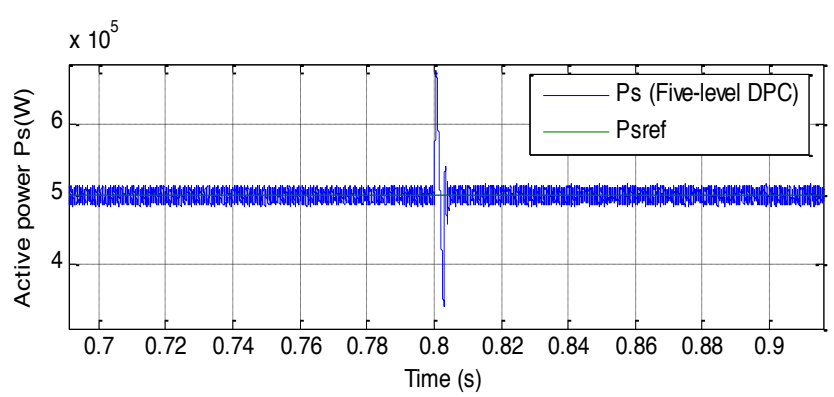

a)DPC

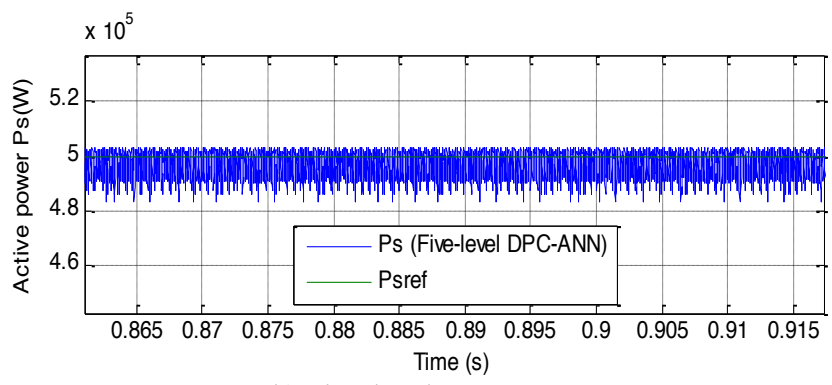

b) Five-level DPC-ANN

Fig. 14 Zoom in the active power (RTT).

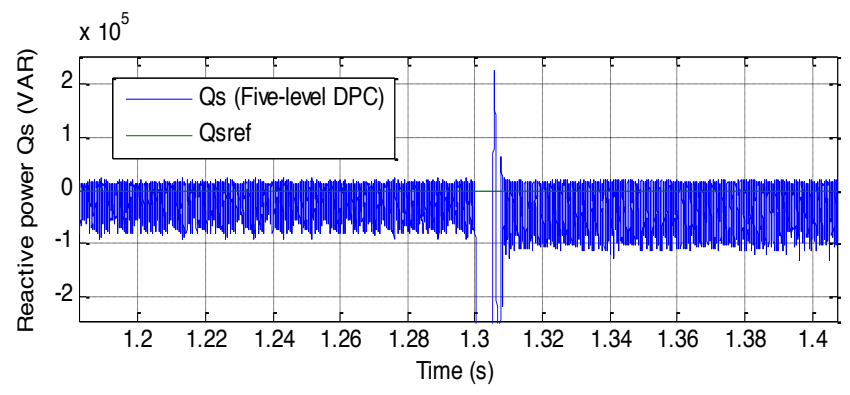

a)DPC

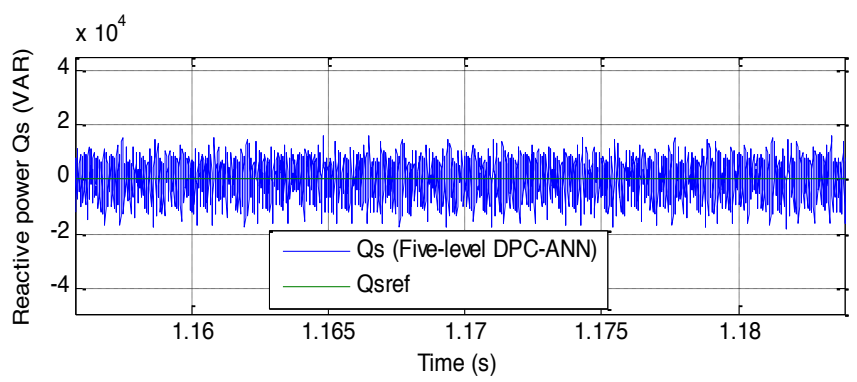

b) Five-level DPC-ANN

Fig. 15 Zoom in the reactive power (RTT).

\section{B.Robustness Test(RT)}

In order to test the robustness of the proposed strategies, the DFIG parameters have been intentionally changed such as the values of the resistances $R_{s}$ and $R_{r}$ are multiplied by 2 and the values of the inductances $L_{s}$ and $L_{r}$ are divided by 2 . Simulation results are presented in Figs. 16-19. As it's shown by these figures, these variations present a clear effect on stator reactive power and stator reactive power and that the effect appears more important for the five-level DPC strategy than that with five-level DPC-ANN control scheme. Thus, it can be concluded that the proposed five-level DPC-ANN control scheme is more robust than the five-level DPC one.

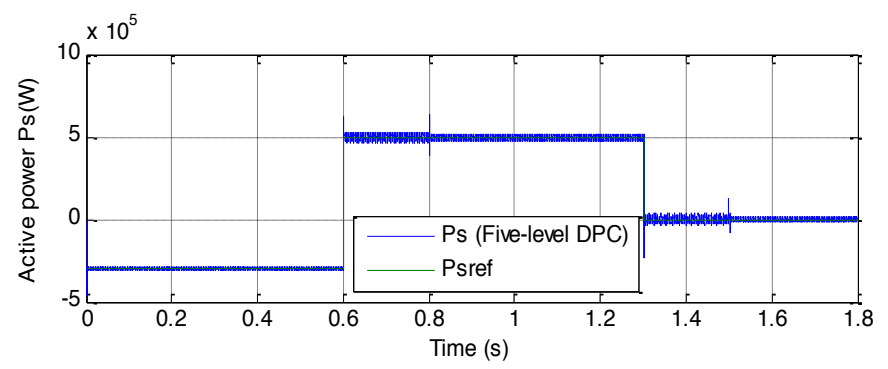

a)DPC 


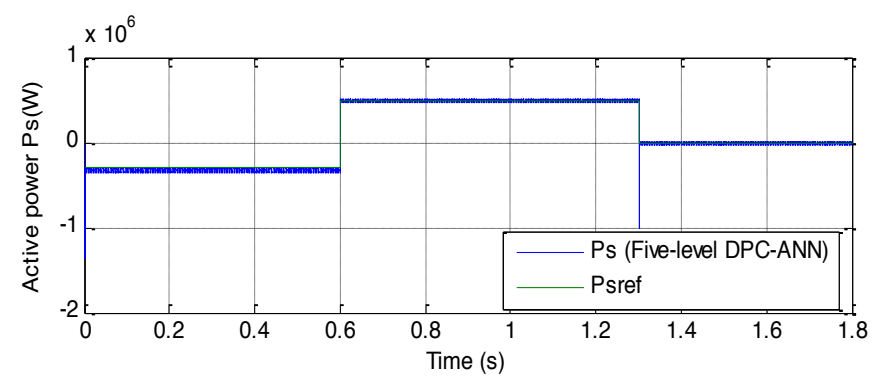

b) Five-level DPC-ANN

Fig. 16 Active power (RT).

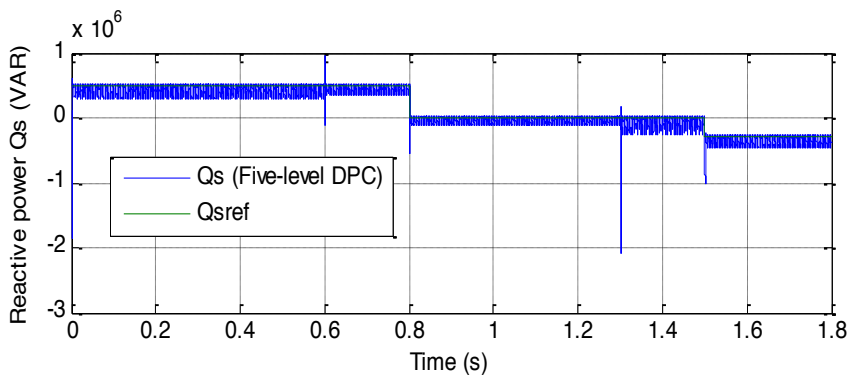

a)DPC

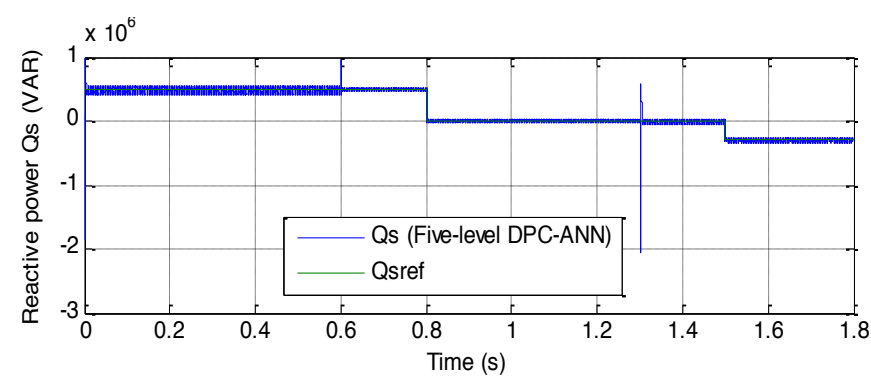

b) Five-level DPC-ANN

Fig. 17 Reactive power (RT).

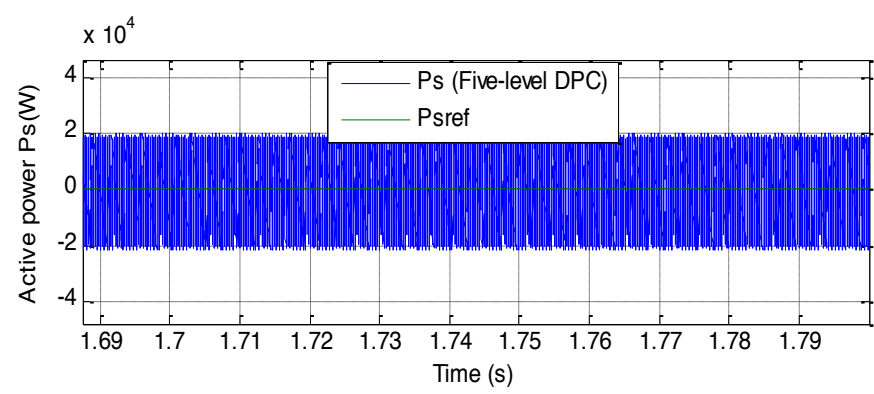

a)DPC

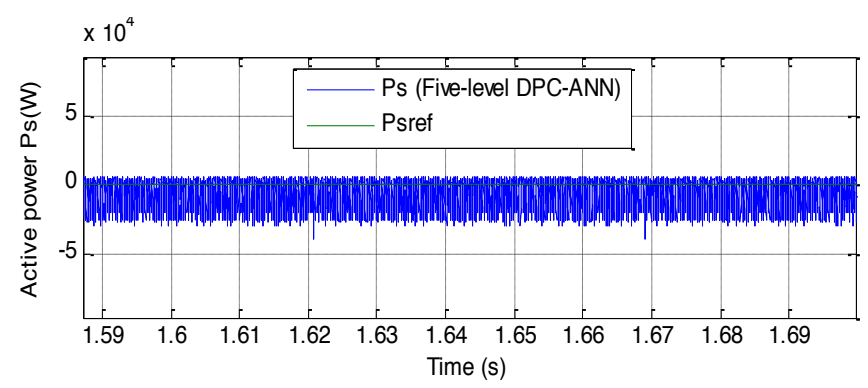

b) Five-level DPC-ANN

Fig. 18 Zoom in the active power (RT).

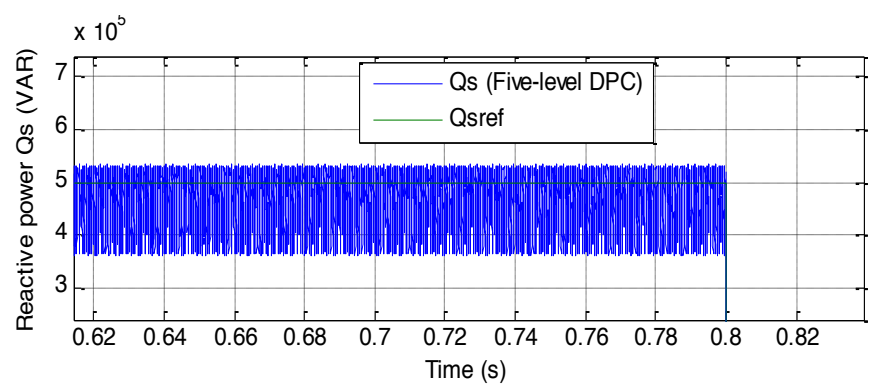

a)DPC

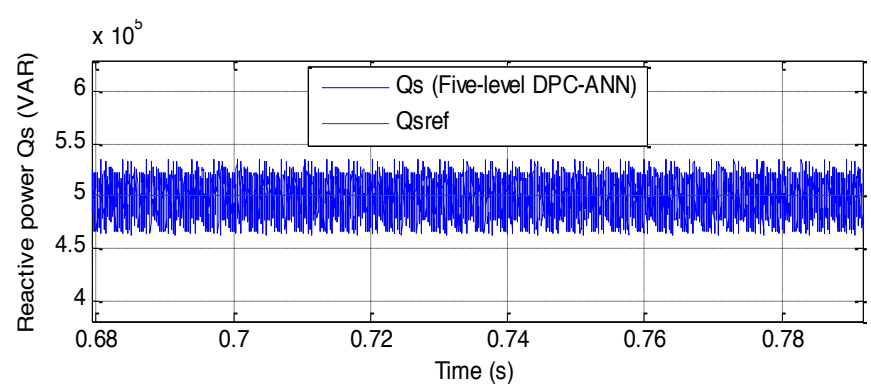

b) Five-level DPC-ANN

Fig. 19 Zoom in the reactive power (RT).

\section{Conclusion}

In this paper, the five-level DPC strategy with neural controller is presented and it is compared with classical fivelevel DPC strategy. The simulation results obtained for the proposed control scheme illustrate a considerable reduction in harmonic distortion of stator current, stator active and reactive ripples compared to the traditional DPC utilizing five-level inverter.

\section{Reference}

[1] A. Boulahia, K. Nabti, H. Benalla, « Direct Power Control for AC/DC/AC Converters in Doubly Fed Induction Generators Based Wind Turbine, » International Journal of Electrical and Computer Engineering, Vol. 2, No. 3, pp. 425-432, 2012. http://dx.doi.org/10.11591/ijece.v2i3.284

[2] M. M. Rezaei, M. Mirsalim, « Improved Direct Torque Control for Induction Machine Drives Based on Fuzzy Sector Theory, » Iranian Journal of Electrical \& Electronic Engineering, Vol. 6, No. 2, pp. 110-118, 2010.

http://ijeee.iust.ac.ir/article-1-294-en.html

[3] D. K. Kumar, G. T. Ram Das, «Simulation and Analysis of Modified DTC of PMSM, » International Journal of Electrical and Computer Engineering, Vol. 8, No. 5, pp. 2894-2903, 2018.

[4] S. Tamalouzt, K. Idjdarene, T. Rekioua, R. Abdessemed, «Direct torque control of wind turbine driven doubly fed induction generator, » Rev. Roum. Sci. Techn.- Électrotechn. et Énerg., Vol. 61, No. 3, pp. 244-249, 2016. 
http://www.revue.elth.pub.ro/viewpdf.php?id=593

[5] Z. Boudjema, R. Taleb, Y. Djerriri, A. Yahdou, « A novel direct torque control using second order continuous sliding mode of a doubly fed induction generator for a wind energy conversion system, ” Turkish Journal of Electrical Engineering \& Computer Sciences, Vol. 25, pp. 965-975, 2017. https://journals.tubitak.gov.tr/elektrik/abstract.htm?i $\mathrm{d}=20284$.

[6] S. Jou, S. Lee, Y. Park, K. Lee, « Direct Power Control of a DFIG in Wind Turbines to Improve Dynamic Responses, » Journal of Power Electronics, Vol. 9, No. 5, pp. 781-790, 2009.

http://wave.ajou.ac.kr/13_2009_09.pdf

[7] S. M. Tavakoli, M. A. Pourmina, M. R. Zolghadri, «Comparison between different DPC methods applied to DFIG wind turbines, » International Journal of Renewable Energy Research, Vol. 3, No. 2, pp. 446-452, 2013.

https://www.ijrernet.ijrer.org/index.php/ijrer/article/view/680/pdf

[8] A. Mirzakhani, R. Ghandehari, S. A. Davari, «A New DPC-based Control Algorithm for Improving the Power Quality of DFIG in Unbalance Grid Voltage Conditions, » International Journal Of Renewable Energy Research, Vol. 8, No.4, pp. 2229-2238, 2018.

https://ijrer.com/index.php/ijrer/article/download/85 $\underline{83 / p d f}$

[9] A. Nazari, H. Heydari, «Direct Power Control Topologies for DFIG-Based Wind Plants, » International Journal of Computer and Electrical Engineering, Vol. 4, No. 4, pp. 475-479, 2012. http://www.ijcee.org/papers/537-N038.pdf

[10] H. Nian, Y. Song, «Direct power control of doubly fed induction generator under distorted grid voltage, » IEEE Transactions on Power Electronics, Vol. 29, No. 2, pp. 894-905, 2014.

https://ieeexplore.ieee.org/stamp/stamp.jsp?arnumb er $=6873337$

[11] S. Massoum, A. Meroufel, B. E. Youcefa, A. Massoum, P. Wira, «Three-level NPC Converterbased Neuronal Direct Active and Reactive Power Control of the Doubly fed Induction Machine for Wind Energy Generation, » Majlesi Journal of Electrical Engineering, Vol. 11, No. 3, pp. 25-32, 2017.

http://mjee.iaumajlesi.ac.ir/index/index.php/ee/articl e/view/2302

[12] A. Mehdi, S. Rezgui, H. Medouce, H. Benalla, «A Comparative Study between DPC and DPCSVM Controllers Using dSPACE (DS1104), »
International Journal of Electrical and Computer Engineering, Vol. 4, No. 3, pp. 322-328, 2014.

https://www.iaescore.com/journals/index.php/IJEC E/article/view/5577/4871

[13] S. Massoum, A. Meroufel, A. Massoum, P. Wira, «A direct power control of the doubly-fed induction generator based on the SVM Strategy, » Elektrotehniški Vestnik, Vol. 84, No. 5, pp. 235$240,2017$.

https://ev.fe.uni-lj.si/5-2017/Massoum.pdf

[14] E. G. Shehata, «Sliding mode direct power control of RSC for DFIGs driven by variable speed wind turbines, » Alexandria Engineering, 2015.

Doi.Org/10.1016/J.Aej.2015.06.006

[15] A. Bouyekni, R. Taleb, Z. Boudjema, H. Kahal, « A second-order continuous sliding mode based on DFIG for wind-turbine-driven DFIG, 》 Elektrotehniški Vestnik, Vol. 85, No. 1-2, pp. 29-36, 2018.

https://ev.fe.uni-lj.si/1-2-2018/Bouyekni.pdf

[16] J. Hu, J. Zhu, D. G. Dorrell, «Predictive direct power control of doubly fed induction generators under unbalanced grid voltage conditions for power quality improvement, » IEEE Transactions on Sustainable Energy, Vol. 6, No. 3, 2015.

https://ieeexplore.ieee.org/xpl/tocresult.jsp?isnumbe $\mathrm{r}=7127072$ \&punumber $=5165391$

[17] H. Benbouhenni, Z. Boudjema, A. Belaidi, « Direct vector control of a DFIG supplied by an intelligent SVM inverter for wind turbine system, » Iranian Journal of Electrical and Electronic Engineering, Vol. 15, No. 1, pp. 45-55, 2019. http://ijeee.iust.ac.ir/article-1-1238-en.html.

[18] H. Benbouhenni, Z. Boudjema, A. Belaidi, « Indirect vector control of a DFIG supplied by a two-level FSVM inverter for wind turbine system, » Majlesi Journal of Electrical Engineering, Vol. 13, No. 1, pp. 45-54, 2019.

http://mjee.iaumajlesi.ac.ir/index/index.php/ee/articl e/view/2693

[19] L. Xu, P. Cartwright, « Direct active and reactive power control of DFIG for wind energy generation, " IEEE Transactions On Energy Conversion, Vol. 21, No. 3, pp. 750-758, 2006. https://ieeexplore.ieee.org/xpl/tocresult.jsp?isnumbe $\mathrm{r}=35284$

[20] M. G. Prakash, M. Balamurugan, S. Umashankar, «A New Multilevel Inverter with Reduced Number of Switches, » International Journal of Power Electronics and Drive System, Vol. 5, No. 1, pp. 63$70,2014$.

http://www.iaesjournal.com/online/index.php/IJPE DS/article/view/6089

[21] H. Benbouhenni, «Five-level DTC with 12 sectors of induction motor drive using neural networks 
INTERNATIONAL JOURNAL Of SMART GRID

Habib Benbouhenni, Vol.3, No.3, September, 2019

controller for low torque ripple, » Acta Electrotechnica et Informatica, Vol. 18 , No. 2, pp. 61-66, 2018.

http://www.aei.tuke.sk/papers/2018/2/20182.htm\#B ENBOUHENNI.

[22] M. V. Kazemi, A. S. Yazdankhah, H. M. Kojabadi, « Direct power control of DFIG based on discrete space vector modulation, » Renewable Energy, Vol. 35, pp. 1033-1042, 2010.

https://doi.org/10.1016/j.renene.2009.09.008 